Dr. Aycan Buldur ${ }^{1}$

Dr. Sivas Cumhuriyet University, Faculty of Education

Department of Early Childhood Education

Sivas , Turkey

Dr. İclal Gokkus ${ }^{2}$

Dr. Sivas Cumhuriyet University, Faculty of Education

Department of Primary Education

Sivas , Turkey
Original scientific paper

UDC: 371.15

DOI: $10.5937 /$ IstrPed2101264B

\title{
THE EFFECT OF MONTESSORI EDUCATION ON THE DEVELOPMENT OF PHONOLOGICAL AWARENESS AND PRINT AWARENESS
}

\begin{abstract}
Montessori education program offers an alternative education opportunity for children, and it supports the development of children in early childhood period as well. In the study, it was aimed to examine the effect of Montessori education on the development of phonological awareness and print awareness, which are among the early childhood literacy skills. This study was conducted in a longitudinal research design. As the data were collected from the same participants, panel design was taken as the basis of the study. The study group was composed of a total of 50 children, 24 boys and 26 girls, in the" 4-6 age" group with normal development who received education in the Montessori class of a state nursery located in Sivas province of Turkey in the 2019-2020 academic year. As data collection tool, the "Scale for Evaluating Early Literacy Skills" (SEELS), which was developed by Karaman Benli (2013) and whose validity and reliability studies were carried out by the same author, was used. In the study, in order to examine whether there was a significant difference between the pretest and posttest scores in the phonological awareness and print awareness of children attending the Montessori Education program, dependent samples t-test was performed. In addition, in order to investigate whether there was a difference between the pretest and posttest scores regarding the participants' phonological awareness and print awareness in terms of gender, two-factor ANOVA test was employed. As a result of the study, it was determined that there was a difference in favor of posttest scores between the pretest and posttest mean scores of children with normal development in the "4-6" age group who were attending the Montessori Education program in terms of general phonological awareness, matching words starting with the same initial sounds, matching rhyming words, noticing the initial sounds of words, omitting sounds and syllables, connecting sounds, and general print awareness skills, and that this difference did not vary according to gender.
\end{abstract}

Keywords: Montessori education, early childhood period, early literacy, phonological awareness, print awareness.

'aycanbuyuktanir@gmail.com

²dagdevireniclal@gmail.com 


\section{Introduction}

Montessori education, which supports the development of children in many respects, attaches great importance to language development, and in Montessori education classrooms, there are all types of materials that will improve the language the child acquires in the linguistic area. Montessori education initially ensures that the child becomes aware of the sounds through sound games in order to support children's verbal language and it helps them to discover the structures of their mother tongue (Toran, 2011). Thus, their receptiveexpressive language skills develop. Teaching reading and writing, which are seen as the direct extension of verbal language, starts indirectly in Montessori education. In a Montessori school, children are primarily prepared for writing by getting them to gain experience in the areas of "daily life exercises, sensory development, motor development, and language development" through various materials. In the Montessori reading-writing approach, the critical element is that teaching and preparing for writing should precede teaching reading (Arndt, 2005). Writing skill is a prerequisite for the development of reading skills, and the works done in order to develop writing skills also constitute the basis for the development of reading skills. In order to develop a child's writing skill, indirect exercises that will develop muscle structures for them to hold and use pencil must be performed. Upon the completion of these works, letters should be introduced. Children should learn the shape of the letters both visually and in a tactile way by using sandpaper letters, by watching the way the letter representing the sound produced by the teacher is written and following the letters in the direction they are written with their fingertips, and associate the sound with the letter (Richardson, 1997). Thanks to the phonological approach applied to children, they understand how the spoken language is coded as words through the symbolic letters of the alphabet, and learn the letters represented by each sound (Seldin, 2014). After the visual perception of the sounds and learning of the shapes and sounds of the letters, they should be made to form words by connecting sounds with movable letters (Richardson, 1997). After this element that provide the development of writing and mechanical reading, or code deciphering is ensured, writing should be left to the responsibility of the child, and the child should not be forced to write. When writing becomes a big discovery, an issue to be proud of and a real pleasure for the child, s/he will start writing by himself/herself. Teaching reading should be started on the day when a child shows an interest in the meaning of written words (Arndt, 2005). Good and effective reading is made up of two processes that complement each other. The first of these is identify a word structurally, that is, to understand that a word is made up of various phonological components; and the second process is to make a linguistic sense of this structure, that is, to ascribe the linguistic meaning to the word that is composed of phonological components and which it mainly carries (Westwood, 2008 as cited in Suel, 2011). In the development of reading-writing skills, early childhood period, which comprises the years starting from birth to formal reading-writing teaching, has an important place. Reading and writing development in the early childhood period is defined as early literacy (Gokkus, 2016). Early literacy is both a stage of literacy process and a prerequisite for the development of literacy, and "it involves all prerequisite knowledge, skills and attitudes that are expected to be gained in relation to reading and writing" (Sulzby \& Teale, 1991; Whitehurst and Lonigan, 1998). Basic skills related to early literacy have usually been expressed as phonological awareness, print awareness, alphabet-letter knowledge and verbal language-vocabulary knowledge (Arrow, 2020; Bayraktar, 2013; Casey \& Sheran; 2004; Cabuk, 2014; French, 2013; Israel, 2001; Karaman, 2013; Pullen \& Justice, 2003; Spivey, 2012; Whitehurst \& Lonigan, 1998; Yazici, 2010). 
Phonological awareness is sensitivity towards sound structures in the oral language and the ability to use the independent phonemes in the word (Anthony \&Francis, 2005). It is being aware of the fact that verbal language can be divided into smaller units (such as obtaining sounds from words, dividing the initial and final sound, separating all sounds of a word one by one, omitting and adding sounds, and creating new words) by using various methods (Chard \&Dickson, 1999). Dividing words into syllables, noticing rhymes, producing rhymes, and determining words starting with the same sound are indicators of phonological awareness at the basic level. Advanced levels of this awareness include more complicated skills such as separating the sounds in a word or syllable into phonemes, connecting phonemes, and changing phonemes (Schuele \& Boudreau, 2008). Being aware of the phonemes forming the word facilitates especially children's understanding of the alphabetical nature of print language (Lane \&Pullen, 2004). In languages in which sound-letter relationship is transparent such as Turkish, it is important for children to gain phonological awareness in order to learn how the words are represented in print form (Gokkus, 2016). Phonological awareness also contributes to the development of alphabetical principles that are required for the acquisition of print word by coding sound properties of the word pronounced. In order to decode the print word, it is necessary to grasp the logic behind the print system and as a prerequisite, the logic behind oral word production (Hempenstall, 1997). The ultimate goal of alphabet-letter knowledge is to learn how sounds match alphabetical letters one by one. Therefore, alphabet knowledge is a step on the road to alphabetical principle and to grasp how a letter represents a speech sound (Pavelko, 2011). Knowledge of letter-sound relationship is a primary skill that facilitates reading words (Chard \& Kameenui, 2000 as cited in Baydik, 2006). Considering that a language is a code built on phonemes, it should be ensured that the phonemic structure of the spoken word is clearly understood in order to decode a print word. That is to say, the child should be able to match the print word with the word s/he hears (Sari, 2012).

Print awareness, on the other hand, is to know that print symbolizes spoken words, and to know the basic properties of print materials (Ergul, Karaman, Akoglu, Tufan, Sarica \& Kudret, 2014). Justice and Ezell evaluated print awareness under four headings as (1) book and print concepts, (2) word concept, (3) alphabet knowledge, and (4) literacy terms. Print awareness includes such task as holding the book in accordance with the direction it is opened, book using skills (book concept), knowing that a book is read from the front to the back and from the top to the bottom, knowing that the first letter of a word is on the left and the last letter on the right (print concept), noticing that words and letters can be named and that they carry a meaning, noticing that words are formed by the combination of different letters, and understanding that words, letters, and numbers are different structures (Stewart \&Lovelace, 2006).

The development of reading writing skills such as print, sound and word awareness in the preschool period supports the development of reading and writing skills in primary school when children start formal education; namely, it constitutes the basis of reading and writing (Taskin, Sak \& Sak, 2015, p. 330). Phonological awareness, alphabet-letter knowledge, word knowledge and print awareness play a significant role as cognitive-linguistic skills in the development of reading-writing skills (Puranik, Lonigan \& Kim, 2011). As Montessori education supports the child in all areas of development, it also contributes to the development of early reading-writing skills (Glenn, 2003). 
Since the child's achievement in reading and writing is related to his/her competence in early literacy skills, the contribution of Montessori education to the development of these skills will also affect his/her achievement in reading and writing skills.

\section{Aim of the study}

In the study, it was aimed to examine the effect of Montessori education on the development of early literacy skills such as "matching words starting with the same initial sounds", "matching rhyming words", "noticing the initial sounds of words", "omitting sounds and syllables", "connecting sounds" and "print awareness". For this purpose, answers to the following research question and its sub-problems were sought.

\section{Research Problem}

Is there a difference in the phonological awareness and print awareness skills of children with normal development in the "4-6 age" group who attend the Montessori Education program as a result of the implementation of the program, and does this difference vary according to gender?

\section{Sub-problems of the research:}

1. Is there a difference between the pretest and posttest mean scores of children attending the Montessori Education program in terms of their phonological awareness such as "matching words starting with the same initial sounds", "matching rhyming words", "noticing the initial sounds of words", "omitting sounds and syllables", "connecting sounds" and "print awareness skills"?

2. Does the difference between the pretest and posttest mean scores of children attending the Montessori Education program regarding their phonological awareness such as "matching words starting with the same initial sounds", "matching rhyming words", "noticing the initial sounds of words", "omitting sounds and syllables", "connecting sounds", and "print awareness skills" vary according to gender?

\section{Importance of the Research}

With the popularization of policies that attach importance to children, studies conducted on early childhood education with different approaches and implementations have become widespread, and a variety of early childhood education approaches have been developed (e.g., Montessori, Reggio Emilia, High Scope, Bank Streer, Head Start, Waldof, Rudolf). One of the early childhood education approaches developed according to the living conditions, needs, cultures and educational understanding of different countries is Montessori education approach. Montessori education approach, which is the representative of child-based movement and is widely used among the alternative education methods, (Korkmaz, 2005), is implemented today in numerous countries such as Russia, the USA, Canada, Mexico, Chili, South Africa Republic, Ethiopia, Tanzania, India, Pakistan, the Netherlands, Germany, and New Zealand (Durakoglu,2011). The interest in this approach in our country is increasing, and it is implemented in many educational institutions both in an integrated and eclectic manner. 
As the ground for literacy skills is laid in early childhood period, early childhood education programs provided in this period and language education included in these programs have an important place in the development of early literacy skills. As early literacy forms the basis of future reading-writing and academic skills, it is important to determine whether preschool education programs prepared in line with Montessori education approach in Turkey are effective in terms of the development of early literacy skills.

When the national literature was examined, it was seen that the number of studies examining the effect of Montessori education program on the development of early literacy skills in children with normal development in the "4-6 age" range is limited (Aydogan, 2016; Eratay, 2009; Kayili, Kocyigit \& Erbay, 2009), and it was observed that only receptive language skills and vocabulary knowledge among early literacy skills were investigated in these studies. However, no study was found that examined the effect of Montessori education on the development of phonological awareness and print awareness, which are the two significant basic skills of early childhood literacy skills. Therefore, in this study, it is considered important that the development in the phonological awareness and print awareness of children in the "4-6 age" range receiving Montessori education is investigated.

\section{Method}

\section{Research Model}

The study, in which it was examined whether there was a change in the phonological awareness and print awareness of children with normal development in the "4-6 age" group who attend the Montessori Education program, was carried out in a longitudinal research design. As the data were collected from the same participants, panel design was taken as the basis of the study (Fraenkel \& Wallen, 2003).

\section{Study Group}

The study group was composed of a total of 50 children, 24 boys and 26 girls, in the "4- 6 age" group with normal development who received education in the "Montessori class" of a state nursery located in Sivas province of Turkey in the 2019-2020 academic year.

\section{Data Collection Tool}

As data collection tool, the "Scale for Evaluating Early Literacy Skills" (SEELS), which was developed by Karaman Benli (2013) and whose validity and reliability studies were carried out by the same author, was used. Within the scope of the study, "phonological awareness assessment test" and "print awareness test" of SEELS were employed. The phonological awareness assessment test is composed of 5 subdimensions (noticing initial sounds, connecting sounds, omitting syllables and sounds, matching words starting with the same sound, and matching rhyming words) and 53 items, and KR-20 internal consistency coefficient of the test is .91. Item difficulty average is $\mathrm{p}=.40$, and distinctiveness index average is $\mathrm{p}=.56$. The print awareness assessment test is made up of 16 items, and KR-20 internal consistency coefficient of the test is .75 , test-retest reliability is $r=.72$, and split-half reliability of the test is 0.60 . 


\section{Data Analysis}

In the study, in order to examine whether there was a significant difference between the pretest and posttest scores in terms of the phonological awareness and print awareness of children attending the Montessori Education program, dependent samples t-test was performed. In addition, in order to investigate whether there was a difference between the pretest and posttest scores regarding the participants' phonological awareness and print awareness in terms of gender, two-factor ANOVA test was used.

\section{Findings}

Findings Regarding the Change in the Pretest and Posttest Mean Scores of Phonological Awareness and Print Awareness

The results of t-test for dependent samples performed in order to examine the development of the participants' early literacy skills regarding the difference between pretest and posttest mean scores obtained from the dimensions of phonological awareness (matching the words starting with the same sound test, matching rhyming words test, noticing the initial sounds of words test, omitting syllables and sounds test, connecting sounds test) and print awareness included in the measurement tool are presented in Table 1.

Table 1. The results of t-test for dependent samples performed regarding the difference between the pretest and posttest mean scores related to the participants' phonological awareness and print awareness

\begin{tabular}{|c|c|c|c|c|c|c|c|c|c|}
\hline Scale & Subdimension & Group & $\mathbf{N}$ & $\bar{X}$ & ss & sd & $t$ & $p$ & $\eta^{2}$ \\
\hline \multirow{12}{*}{$\begin{array}{l}\text { Phonological } \\
\text { Awareness }\end{array}$} & \multirow{2}{*}{$\begin{array}{l}\text { General Phonological } \\
\text { Awareness }\end{array}$} & Pretest & 50 & 22.04 & 10.33 & \multirow[t]{2}{*}{49} & \multirow[t]{2}{*}{7.664} & \multirow[t]{2}{*}{$<.01$} & \multirow[t]{2}{*}{.55} \\
\hline & & Posttest & 50 & 28.74 & 9.46 & & & & \\
\hline & \multirow{2}{*}{$\begin{array}{l}\text { Matching the Words } \\
\text { Starting with the Same } \\
\text { Sound }\end{array}$} & Pretest & 50 & 4.06 & 1.80 & \multirow[t]{2}{*}{49} & \multirow[t]{2}{*}{4.523} & \multirow[t]{2}{*}{$<.01$} & \multirow[t]{2}{*}{.29} \\
\hline & & Posttest & 50 & 4.78 & 1.25 & & & & \\
\hline & \multirow{2}{*}{$\begin{array}{l}\text { Matching Rhyming } \\
\text { Words }\end{array}$} & Pretest & 50 & 5.70 & 2.52 & \multirow[t]{2}{*}{49} & \multirow[t]{2}{*}{4.319} & \multirow[t]{2}{*}{$<.01$} & \multirow[t]{2}{*}{.28} \\
\hline & & Posttest & 50 & 6.28 & 2.00 & & & & \\
\hline & \multirow{2}{*}{$\begin{array}{l}\text { Noticing the Initial } \\
\text { Sounds of Words }\end{array}$} & Pretest & 50 & 8.56 & 5.78 & \multirow[t]{2}{*}{49} & \multirow[t]{2}{*}{6.634} & \multirow[t]{2}{*}{$<.01$} & \multirow[t]{2}{*}{.47} \\
\hline & & Posttest & 50 & 11.82 & 4.90 & & & & \\
\hline & \multirow{2}{*}{$\begin{array}{l}\text { Omitting Syllables and } \\
\text { Sounds }\end{array}$} & Pretest & 50 & 2.26 & 2.86 & \multirow[t]{2}{*}{49} & \multirow[t]{2}{*}{5.870} & \multirow[t]{2}{*}{$<.01$} & \multirow[t]{2}{*}{.41} \\
\hline & & Posttest & 50 & 3.20 & 2.75 & & & & \\
\hline & \multirow[t]{2}{*}{ Connecting Sounds } & Pretest & 50 & 1.48 & 1.91 & \multirow[t]{2}{*}{49} & \multirow[t]{2}{*}{6.062} & \multirow[t]{2}{*}{$<.01$} & \multirow[t]{2}{*}{.43} \\
\hline & & Posttest & 50 & 2.68 & 2.00 & & & & \\
\hline \multirow{2}{*}{$\begin{array}{l}\text { Print } \\
\text { Awareness } \\
\text { Awareness }\end{array}$} & \multirow{2}{*}{$\begin{array}{l}\text { General Print } \\
\text { Awareness }\end{array}$} & Pretest & 50 & 11.28 & 2.63 & \multirow[t]{2}{*}{49} & \multirow[t]{2}{*}{7.400} & \multirow[t]{2}{*}{$<.01$} & \multirow[t]{2}{*}{.53} \\
\hline & & Posttest & 50 & 13.44 & 1.62 & & & & \\
\hline
\end{tabular}

As seen in Table 1, significant differences in favor of posttest were found between pretest and posttest mean scores in terms of general phonological awareness $(t(49)=7.664, p<.01$, EtaSquare: .55), matching the words starting with the same sound $(t(49)=4.523, p<.01$, EtaSquare: .29), matching rhyming words $(t(49)=4.319, p<.01$, Eta-Square: .28$)$, noticing the initial sounds of words $(t(49)=6.634, p<.01$, Eta-Square: .47$)$ and omitting syllables and sounds $(t(49)=5.870, p<.01$, Eta-Square: .41$)$ connecting sounds $(t(49)=6.062, p<.01$, EtaSquare: .43), general print awareness $(t(49)=7.400, p<.01$, Eta-Square: .53$)$. Impact size values calculated for the significance of the differences between pretest and posttest mean scores show that differences have a high level of impact on all skill levels (Pallant, 2007). In the light 
of this information, participants improved significantly upon receiving education in the Montessori class compared to pre-education period.

\section{Findings Regarding the Change in the Pretest and Posttest Mean Scores of Phonological Awareness and Print Awareness by Gender}

The results of the two-factor ANOVA test performed in order to determine whether the difference varied by gender between pretest and posttest mean scores obtained from the dimensions of phonological awareness (matching the words starting with the same sound test, matching rhyming words test, noticing the initial sounds of words test, omitting syllables and sounds test, connecting sounds test) and print awareness included in the measurement tool in order to examine the development in the participants' early literacy skills are presented in Table 2.

Table 2. The results of the two-factor ANOVA test performed regarding the difference between the pretest and posttest mean scores related to the participants' phonological awareness and print awareness by gender

\begin{tabular}{|c|c|c|c|c|c|c|c|c|c|c|c|c|}
\hline \multirow[b]{2}{*}{ Scale } & \multirow[b]{2}{*}{ Subdimension } & \multirow[b]{2}{*}{ Group } & \multicolumn{3}{|c|}{ Pretest } & \multicolumn{3}{|c|}{ Posttest } & \multicolumn{4}{|c|}{ Two-Factor ANOVA } \\
\hline & & & $\mathbf{N}$ & $\bar{X}$ & ss. & $\mathrm{N}$ & $\bar{X}$ & ss. & V.K & sd & F & $\mathbf{p}$ \\
\hline \multirow{12}{*}{$\begin{array}{c}\text { Phonological } \\
\text { Awareness }\end{array}$} & \multirow{2}{*}{$\begin{array}{l}\text { General } \\
\text { Phonological } \\
\text { Awareness }\end{array}$} & Girl & 26 & 20.92 & 8.78 & 26 & 28.31 & 8.12 & $A \times G$ & 1 & \multirow[t]{2}{*}{0.660} & \multirow[t]{2}{*}{$>.05$} \\
\hline & & Boy & 24 & 23.25 & 11.87 & 24 & 29.21 & 10.88 & Error & 48 & & \\
\hline & \multirow[b]{2}{*}{$\begin{array}{l}\text { Matching the } \\
\text { Words } \\
\text { Starting with } \\
\text { the Same } \\
\text { Sound }\end{array}$} & Girl & 26 & 4.38 & 1.60 & 26 & 5.08 & 1.13 & $A \times G$ & 1 & \multirow[t]{2}{*}{0.032} & \multirow[t]{2}{*}{$>.05$} \\
\hline & & Boy & 24 & 3.71 & 1.97 & 24 & 4.46 & 1.32 & Error & 48 & & \\
\hline & \multirow{2}{*}{$\begin{array}{l}\text { Matching } \\
\text { Rhyming } \\
\text { Words }\end{array}$} & Girl & 26 & 5.61 & 2.73 & 26 & 6.31 & 2.07 & $A \times G$ & 1 & \multirow[t]{2}{*}{0.342} & \multirow[t]{2}{*}{$>.05$} \\
\hline & & Boy & 24 & 5.79 & 2.32 & 24 & 6.25 & 1.96 & Error & 48 & & \\
\hline & \multirow{2}{*}{$\begin{array}{l}\text { Noticing the } \\
\text { Initial Sounds } \\
\text { of Words }\end{array}$} & Girl & 26 & 8.38 & 8.37 & 26 & 12.15 & 4.36 & $A \times G$ & 1 & \multirow[t]{2}{*}{1.167} & \multirow[t]{2}{*}{$>.05$} \\
\hline & & Boy & 24 & 8.75 & 6.31 & 24 & 11.46 & 5.49 & Error & 48 & & \\
\hline & \multirow{2}{*}{$\begin{array}{l}\text { Omitting } \\
\text { Syllables and } \\
\text { Sounds }\end{array}$} & Girl & 26 & 1.23 & 1.86 & 26 & 2.35 & 2.02 & $A \times G$ & 1 & \multirow[t]{2}{*}{1.308} & \multirow[t]{2}{*}{$>.05$} \\
\hline & & Boy & 24 & 3.37 & 3.33 & 24 & 4.12 & 3.15 & Error & 48 & & \\
\hline & \multirow{2}{*}{$\begin{array}{l}\text { Connecting } \\
\text { Sounds }\end{array}$} & Girl & 26 & 1.11 & 2.05 & 26 & 2.35 & 1.96 & $A \times G$ & 1 & \multirow[t]{2}{*}{0.026} & \multirow[t]{2}{*}{$>.05$} \\
\hline & & Boy & 24 & 1.87 & 1.70 & 24 & 3.04 & 2.03 & Error & 48 & & \\
\hline \multirow{2}{*}{$\begin{array}{c}\text { Print } \\
\text { Awareness }\end{array}$} & \multirow{2}{*}{$\begin{array}{l}\text { General Print } \\
\text { Awareness }\end{array}$} & Girl & 26 & 11.69 & 2.22 & 26 & 13.61 & 1.58 & $A \times G$ & 1 & \multirow[t]{2}{*}{0.710} & \multirow[t]{2}{*}{$>.05$} \\
\hline & & Boy & 24 & 10.83 & 2.99 & 24 & 3.25 & 1.67 & Error & 48 & & \\
\hline
\end{tabular}

*Source of Variance AxG=(Application)x(Gender)

As seen in Table 2, according to the two-factor ANOVA test results performed in order to determine whether the differences observed in the pretest and posttest scores of the girl and boy participants regarding the total scores of the subdimensions of phonological awareness and print awareness, no significant difference was found between the pretest and posttest total scores of the subdimensions in terms of general phonological awareness $(F(1.48)=0.660, p>.05)$, matching words starting with the same sound $(F(1.48)=0.032, p>.05)$, matching rhyming words $(F(1.48)=0.342, p>.05)$, noticing the initial sounds of words $(F(1.48)=1.167, p>.05)$ and omitting syllables and sounds $(F(1.48)=1.308, p>.05)$ connecting sounds $(F(1.48)=0.026, p>.05)$, general print awareness $(F(1.48)=0.710, p>.05)$. This situation 
indicates that the common effects of repetitive measurements (pretest-posttest) factors with different genders on students' phonological awareness (matching words starting with the same sound test, matching rhyming words test, noticing the initial sounds of words test, omitting syllables and sounds test, connecting sounds test) and print awareness are not significant.

\section{Discussion}

In the study, the effect of Montessori education program on the development of the phonological awareness and print awareness of children with normal development in the "4-6 age" group was examined. As a result of the study, it was determined that there was a difference in favor of posttest mean scores between the pretest and posttest mean scores of children with normal development in the "4-6" age group who were attending the Montessori Education program regarding their skills in terms of general phonological awareness, matching words the same initial sounds, matching rhyming words, noticing the initial sounds of words, omitting sounds and syllables, connecting sounds, and general print awareness, and it was found that this difference did not vary according to gender.

Similar to the results reached in this study; McCladdie (2006) examined the effect of Montessori method on the teaching of reading and found that Montessori method was more effective in teaching reading to children compared to the traditional method. Lillard and Heise (2016) reported that children in the 3-6 age range receiving education in classes where Montessori method materials were used were more successful in early reading and early mathematics tests. In their research, Kayili and Ari (2011) concluded that Montessori education positively affected children's readiness level for elementary education. In the studies conducted by Prendergast (1969) and Kayili et al. (2009), it was determined that Montessori education had a positive effect on children's receptive language skills.

In the study they conducted in Croatia, Franc and Subotic (2015) compared phonological awareness in preschool children who received education in Montessori method and those who were educated in the normal preschool education program. As a result of the research, they concluded that Montessori method developed children's phonological awareness, and that it positively contributed to their early reading skills. In his study, Aranas (2016) found that phonological awareness education prepared by using Montessori materials developed phonological awareness and especially the skill of dividing into phonemes. Norman (2020) stated that the exercises done by using sandpaper letters developed children's skill of recognizing the sounds of the letters shown, and that consequently this skill helped develop print, phonological and phonemic awareness. In the present study, it was found that a positive change occurred in phonological awareness and print awareness of children with normal development in the "4-6 age" group who attend the Montessori Education program as a result of the implementation of the program, and that this difference did not vary according to gender. These findings are in parallel with the results of other studies.

In order for children to learn reading-writing, they need to notice print and oral language and make connections between these. Children need to gain phonological awareness in order to learn phonological knowledge related to the structure of oral language and print awareness and alphabet knowledge in order to learn the concept of writing and alphabet knowledge related to the structure of print language (Gokkus, 2016). Kargin, Buyukozturk and Guldenoglu (2015) stated that the development of phonological awareness is more difficult in children 
who do not have letter knowledge, and that therefore, combination of the teaching of these two skills would accelerate learning process more compared to the teaching of them separately. Vocabulary and print awareness along with phonological awareness are considered as the fundamental building blocks of traditional literacy (Justice \& Ezell, 2001). Phonological awareness (Felton, 1992; Israel, 2008; Justice \& Pullen, 2003), print awareness (Justice \& Pullen, 2003; Lonigan, Burgess \& Anthony, 2000; Piasta, Justice, McGinty \& Kaderavek, 2012), and alphabet knowledge and letter-sound matching (Hammill, 2004; Storch \& Whitehurst, 2002; Treiman, Kessler \& Pollo, 2006) are directly associated with reading and writing skills and are the most reliable predictors. Insufficiency in these skills is directly related to insufficiency in reading-writing skills. These skills play an important role in both the acquisition of and achievement in reading-writing skills. Most of these skills are acquired in early childhood period. Through providing effective language education programs aimed at these skills, this insufficiency can be compensated, and these skills are developed (Allain, 2001; Bayraktar, 2013; Bhat, 2000; Biwer, 2002; Bjarnadottir, 2003; Jones, Clark \& Reutzel, 2013; Justice \& Ezell, 2002; McBride-Chang, 1999; Piasta, Purpura \& Wagner, 2010; Qi \& O'Connor, 2000; Senechal \& LeFevre, 2002). As the development of these skills will improve reading and writing skills, it is important to have and implement various language teaching methods, activities and materials aimed at these skills in early childhood period.

There are different approaches regarding language development and supporting it in early childhood period in the literature. One of these approaches is Montessori's views. Maria Montessori also sees language education as the focal point of school education (Kayili et al., 2009), and deals with language education holistically. Reading-writing education constitutes a significant part of the method she has put forth (Durakoglu, 2010). To Montessori, language is acquired in the time span starting from birth to age 6 . In this period, children deprived of linguistic stimuli display linguistic disorders in the following years. In this sensitive period, all stimuli required for linguistic development and acquisition should be regularly provided to the child. An environment prepared for this to happen should be created (Temel \& Toran, 2013). In Montessori schools, reading-writing education is carried out directly through materials within the framework of "self-education" principle (Durakoglu, 2010). This ensures that the child learns the language more effectively and permanently.

As a result of her experiences, Montessori developed handled cylinders and geometrical drawers which she used for indirect preparation purposes, and metal molds, sandpaper letters, movable alphabet and object name cards which she used directly in reading-writing education (Yildirim, 2019), and used a method comprising of three stages in reading writing education.

Montessori concluded that reading and writing is closely associated, and children are able to write before moving on to reading (Ulutas \& Tutkun, 2017), that writing develops easily and automatically in young children as speaking does, and it develops before reading, and that since reading is learned very easily after writing is learned, it is a skill that should be handled after writing (Cakiroglu Wilbrant, 2014). Montessori stated that indirect preparation for print language involves all experiences of a child such as daily life skills, exercises that ensure handeye coordination, receptive skills, aural and visual distinction skills, matching and distinguishing skills (Richardson, 1997). According to Montessori, all children feel curiosity about what the things taught to them in the abstract form look like. If children are taught what a sound looks like and how it is, they learn the letter of the sound by connecting the sound and the letter (Temel \& Toran, 2013). In Montessori schools, sandpaper is used in order 
to teach the child the letters (Durakoglu, 2010). In the exercise done with sandpaper, while the child is touching the letter, the teacher pronounces the sound belonging to that letter (Durakoglu, 2010). With sandpaper/embossed letters, it is aimed primarily for the child to perceive the written form of the sounds s/he is studying by touching and visually, and secondly to support the development of writing skill. With sandpaper/embossed letters, only the print form of letters is taught. It is definitely not recommended to make the child form syllables or words (Cakiroglu Wilbrant, 2014) Teaching of letters are realized through a threestage lesson application in Montessori education. Exercises done with sandpaper letters and letter teaching enhances children's phonological awareness and enables them to analyze the sounds and syllables that form the words spoken (Richardson, 1997). This process is of a preliminary preparation not only for writing but also for reading (Durakoglu, 2010). While children are working with sandpaper letters, they discover the pronunciation and shape of these sounds. As their command of the relationship between the sound and the letter increases, their ability to analyze the sounds of spoken words improves, and children begin the process of forming words (Richardson, 1997). After preparation works for writing, sound cards (Yildirim, 2019) and sound studies with miniature objects are benefited from in order for children to distinguish between the sounds. Liberman (1979) stated that literate individuals who efficiently use the principles of the alphabet should be aware of the phonological structure represented by letters (as cited in Richardson, 1997). Phonological connection hypothesis (Hatcher, 1994) claims that establishing a connection between children's knowledge of the sound structure of words and their print representations will be more effective in the teaching of phonological awareness or the teaching of reading (Gillon, 2007).

In the second stage of Montessori's reading and writing education method, movable letters are used in order for children to recognize and discover the letters by sounds (Korkmaz, 2006). As the connection between sound and print symbol gradually increases, various studies start to be performed by using movable letters. Some of these are studies aimed at phonological awareness. Alphabet knowledge is a skill that forms the basis of phonological awareness and develops along with phonological awareness (Karakelle, 2004, p.55) The main purpose of the studies carried out with movable letters is to enable the child to form words by connecting the movable letters with sounds, to understand that words are made up of sounds (analysis), and to form different words from the sounds in a word (synthesis). These studies can be implemented starting from age 4.5 (Cakiroglu Wilbrant, 2014). These studies develop the child's both phonological awareness and print awareness. If the child is not aware of the fact that reading is done from left to right and from top to bottom, or that the page on the left is read first, s/he is not aware of the fact that words are made up of letters and that different words are formed by arranging the letters in different forms, s/he does not recognize lower and uppercase letters and punctuation marks; namely, if s/he does not have the knowledge about the properties of print language, s/he will have difficulty in learning reading (Oztunc, 1994, p.84) According to Carroll, Bowyer-Crane Duff, Hulme, Margaret and Snowling (2011, p.8), phonological awareness and print awareness interact with each other, and these two essential skills play an important role in the acquisition of reading skills.

In the third stage of the Montessori method of reading and writing education, exercises are done for children to learn reading (Korkmaz, 2006). For this purpose, reading boxes prepared with miniature objects, reading cards about the items around, print picture cards (categorization), task cards and picture reading books can be used. The general purpose of reading materials is to enable the child to understand print symbols and to gain speed in reading (Cakiroglu Wilbrant, 2013). As can be understood, the exercises and material used in 
the Montessori method of reading and writing education directly and indirectly support the child's development in terms of phonological awareness, print awareness, alphabet knowledge and receptive language-vocabulary knowledge, and they accelerate the transition to reading-writing process.

\section{Conclusion and Recommendations}

As a result of the study, it was determined that there was a difference in favor of posttest scores between the pretest and posttest mean scores of children with normal development in the "4-6" age group who were attending the Montessori Education program in terms of general phonological awareness, matching words starting with the same initial sounds, matching rhyming words, noticing the initial sounds of words, omitting sounds and syllables, connecting sounds, and general print awareness skills, and that this difference did not vary according to gender.

Based on this effect of Montessori education on the development of children's literacy skills, additional materials that include Montessori reading-writing applications aimed at early childhood education can be prepared. In this study, the effect of Montessori education on reading and writing skills in the preschool period was examined. In new studies, this relationship can be examined in different age groups.

\section{References}

Allain, S. M.(2001). Effectiveness of a phonemic awareness intervention with four- and five-yearolds. (Doctoral Dissertation). The Texas Woman's University, USA.

Anthony, J. \& Francis. D. (2005) Development of phonological awareness. Current Direction In Psychological Science, Vol.14(5), 255-259.

Aranas, S. A. (2016). Filling the gap: phonological awareness activities for a Montessori

Arndt, J. J. (2005). Literacy outcomes of Montessori-trained students under alternative instructional conditions. (Doctoral Dissertation), Purdue University.

Arrow, A. W. (2010). Emergent literacy skills in New Zealand kindergarten children: implications for teaching and learning in ECE settings. He Kupu, 2(3), 57-69.

Aydogan, Y. (2016). Examination of the affect of Montessori education on language development of pre-school children. Academic Research International, Vol. 7(5), 112-119.

Baydik, B. (2006). Okuma guclugu olan cocuklarin sozcuk okuma becerileri. Ankara Universitesi Egitim Bilimleri Fakultesi Ozel Egitim Dergisi, 7(1), 29-36.

Bayraktar, V. (2013). Okuma-yazmaya hazirlik egitim programinin anasinifina devam eden 6 yas grubu cocuklarin yazi farkindaligi becerilerine ve ilkokul birinci siniftaki ses farkindaligi ve okuma-yazma becerilerine etkisinin incelenmesi. (Doktora Tezi). Gazi Universitesi Egitim Bilimleri Enstitusu, Ankara.

Bhat, P. (2000). Phonological awareness instruction for middle school students with learning disabilities. (Doctoral Dissertation). University of Florida, USA.

Biwer, D. L. (2002). Effects of three phonological awareness programs on kindergarten students identified as at risk for reading failure. (Doctoral Dissertation). Loyola University Chicago, USA.

Bjarnadottir, G. (2003). The effects of phonological awareness instruction on phonological awareness and reading skills. (Doctoral Dissertation). Pennsylvania State University, USA. 
Cabuk, B. (2014). Anasinifi ve sinif ogretmenlerinin okuma yazmaya hazirlik etkinlikleriyle ilgili algi ve bilgi duzeyleriyle mesleki yeterliklerine iliskin algi duzeylerinin karsilastirilmasi. (Doktora tezi). Gazi Universitesi Egitim Bilimleri Enstitusu, Ankara.

Cakiroglu-Wilbrant E. (2014). Okul oncesi egitimde Montessori yaklasimi. Kok Yayincilik.

Casey, A.\&Sheran, C. (2004). Early literacy skills development. National Association of School Psychologists. http://www.ws.k12.ny.us/Downloads/EarlyLit.pdf

Casey, C. M., Cook-Cottone, C. \& Baker, C. N. (2012). A pilot study of effects of the magic penny early literacy program on phonemic awareness and basic reading skills. The New School Psychology Bulletin, 9(2), 74-84

Chard, D. J. \& Dickson S. V. (1999). Phonological awareness: instructional and assessment guideliness. Intervention in School and Clinic, 34(5), 261-270.

Durakoglu, A. (2010). Montessori metodunda okuma ve yazma egitimi. Sosyal Politika Calismalari Dergisi, 20(20), 91-104.

Durakoglu, A. (2011). Montessori sisteminin turkiye'nin okul oncesi egitim sistemiyle karsilastirilmasi. 20. Ulusal Egitim Bilimleri Kurultayi, Burdur. https://www.pegem.net/Akademi/kongrebildiri detay.aspx?id=125048

Eratay, E. (2011). Efficiency of montessori method. Pegem Egitim ve Ogretim Dergisi, 1(1), 11-19.

Ergul, C., Karaman, G., Akoglu, G., Tufan, M., Sarica, A. D. \& Kudret, Z. B. (2014). Okul oncesi ogretmenlerinin "erken okuryazarlik" kavramina iliskin bilgi duzeyleri ve sinif uygulamalari. Ilkogretim Online, 13(4).

Felton, R. H. (1992). Early identification of children at risk for reading disabilities. Topics in Early Childhood Special Education. 12 (2), 212-219.

Filipan-Zignic, L. Zergollern-Miletic, \&l. Gruic (Eds.), Researching paradigms of childhood and education conference book of selected papers (2nd Symposium: Child language and culture, pp. 12-20). Faculty of Teacher Education University of Zagreb.

Fraenkel, J. R. \& Wallen, N. E. (2003). How to design and evaluate research in education (5nd Ed.). McGraw Hill.

French, G. (2013). Early literacy and numeracy matters. https://arrow.dit.ie/cgi/viewcontent.cgi?article=1065\&context=aaschsslarts.

From montessori classrooms associated with better child outcomes. Journal of Montessori Research, 2(1), 16-26.

Gillon, G. T., (2007). Phonological Awareness from Research to Practice. Guilford.

Glenn, C. M. (2003). The Longitudinal Assessment Study (LAS): Eighteen Year Follow-Up. Final. fromhttps://files.eric.ed.gov/fulltext/ED478792.pdf.

Gokkus, I. (2016). Erken okuryazarlik becerilerinin gelisiminde ses bilgisi farkindalik programinin etkisi. (Doktora Tezi). Gazi Universitesi Egitim Bilimleri Enstitusu, Ankara.

Hammill, D. D. (2004). What we know about correlates of reading. Exceptional Children, 70, 453-468.

Hatcher, L. (1994). A step-by-step approach to using the SAS(R) system for factor analysis and structural equation modeling. SAS Institute.

Hempenstall, K. (1997). The role of phonemic awareness in beginning reading: A Review, s.132.https://www.researchgate.net/profile/Kerry_Hempenstall/publication/287116492_Th e_Role_of_Phonemic_Awareness_in_Beginning_Reading_A_Review/links/56d969770 8aebabdb-̄of7003/The-Role-of-Phonemic-Awareness-in-Beginning-Reading-A-Review

Israel, S. E. (2008). Early reading first and beyond: A guide to building early literacy skills. Corwin.

Jones, C. D., Clark, S. K. \& Reutzel, D. R. (2013). Enhancing alphabet knowledge instruction: Research implications and practical strategies for early childhood educators. Early Childhood Education Journal, 41(2), 81-89. 
Justice, L. M. \& Ezell, H. K. (2001). Word and print awareness in 4-year-old children. Child Language Teaching and Therapy, 17(3), 207-225.

Justice, L. M. \& Ezell, H. K. (2002). Use of storybook reading to increase print awareness in atrisk children. American Journal of Speech-Language Pathology, 11(1), 17.

Justice, L.M. \& Pullen, P. C. (2003). Promising interventions for promoting emergent literacy skills: three evidence-based approaches. Topics in Early Childhood Special Education, 23, 99-113.

Karaman, G. (2013). Erken okuryazarlik becerilerini degerlendirme aracinin gelistirilmesi, gecerlik ve guvenirlik arastirmasi. (Doktora Tezi). Gazi Universitesi, Egitim Bilim Enstitusu, Ankara.

Kargin, T., Ergul, C., Buyukozturk, S. \&Guldenoglu, B. (2015). Anasinifi cocuklarina yonelik erken okuryazarlik testi (EROT) gelistirme arastirmasi. Ankara Universitesi Egitim Bilimleri Fakultesi Ozel Egitim Dergisi, 16(03), 237-268.

Kayili, G. \& Ari, R. (2011). Examination of the effects of the Montessori method on preschool children's readiness to primary education. Educational Sciences: Theory and Practice, 11(4), 2104-2109.

Kayili, G., Kocyigit, S. \&Erbay, F. (2009). Montessori yonteminin bes-alti yas cocuklarinin alici dil gelisimine etkisinin incelenmesi. Selcuk Universitesi Turkiyat Arastirmalari Dergisi, 1(26), 347-355.

Korkmaz, E, (2005). Montessori Metoduve Montessori Okullari: Turkiye'de Montessori Okullarinin Yonetim ve Finansman Bakimindan Incelenmesi. (Yayinlanmamis Yuksek Lisans Tezi). Marmara Universitesi, Egitim Bilimleri Enstitusu, Istanbul.

Lane, H. B. \& Pullen, P. C. (2004). Phonological awareness assessment and instruction: A sound beginning. Pearson/A and $B$.

Lillard, A. S. \& Heise, M. J. (2016). An intervention study: Removing supplemented materials

Lonigan, C. J., Burgess, S. R.\& Anthony, J. L. (2000). Development of emergent literacy and early reading skills in preschool children: Evidence from a latent-variable longitudinal study. Developmental Psychology, 36, 596-613.

McBride-Chang, C. (1999). The ABCs of the ABCs: The development of letter-name and lettersound knowledge. Merrill-Palmer Quarterly, 45, 285-308.

McCladdie, K. (2006). A comparison of the effectiveness of the montessori method of reading instruction and the balanced literacy method for inner city africanamerican students.(Unpublished Thesis of Doctor). Saint Joseph's University, Philadelphia.

Norman, E. (2020). Cultivating Toddler Emergent Literacy Behaviors Using the Montessori

Pavelko, S. L. (2011). Emergent writing skills in preschool children with language impairment.(Doctoral These). University of Central Florida.

Piasta, S. B., Justice, L. M., McGinty, A. S., \& Kaderavek, J. N. (2012). Increasing young children's contact with print during shared reading: longitudinal effects on literacy achievement. Child Development, 83(3), 810-820.

Pullen, P. C. \& Justice, L. M. (2003). Enhancing phonological awareness, print awareness, and oral language skills in preschool children. Intervention in school and clinic, 39(2), 87-98.

Puranik, C. S., Lonigan, C. J. \& Kim, Y. S. (2011). Contributions of emergent literacy skills to name writing, letter writing, and spelling in preschool children. Early Childhood Research Quarterly, 26(4), 465-474.

Richardson, S. O. (1997). The montessori preschool: preparation for writing and reading. Annals of Dyslexia, 47(1), 239-256.

Sari, B. (2012). Erken cocukluk donemi fonolojik duyarlilik olcegi (ecdfdo)'nin gecerlik, guvenirlik ve norm arastirmasi. (Yuksek Lisans Tezi). Canakkale Onsekiz Mart Universitesi Egitim Bilimleri Enstitusu, Canakkale. 
Schuele, C. M. \& Boudreau, D. (2008). Phonological awareness intervention: Beyond the basics. Language, Speech, and Hearing Services in Schools, 39(1), 3-20.

Seldin, T. (2014). Montessori yontemiyle harika cocuk nasil yetistirilir? (T. I. Ercan, Cev.). Kaknus Yayinevi.

Senechal, M. \& LeFevre, J. A. (2002). Parental involvement in the development of children's reading skill: A five-year longitudinal study. Child development, 73(2), 445-460.

Spivey, B. L. (2012). Six early literacy skills predict reading and writing success. Handy Handouts. http://www.handyhandouts.com/pdf/378_Literacy_Skills.pdf.

Stewart, S. R. \& Lovelace, S. M. (2006). Recruiting children's attention to print during shared reading. Clinical approaches to emergent literacy intervention, 327-356.

Storch, S. A. \& Whitehurst, G. J. (2002). Oral language and code-related precursors to reading: Evidence from a longitudinal structural model. Developmental Psychology, 38, 937-947.

Suel, E. E. (2011). Illkogretim 1. sinif ustun ve normal zeka duzeyindeki ogrencilerin fonolojik farkindalik duzeylerinin okuma basarilari uzerine etkisinin karsilastirilmasi. (Unpublished master's thesis). Istanbul University, Istanbul.

Sulzby, E. \& Teale, W. (1991). Emergent literacy. Handbook of reading research, 2, 727-757.

Taskin, N., Sak, R. \& Sak, I. T. S. (2015). Okul oncesi donemde okuma yazma ogretimi: ogretmen gorusleri. Hacettepe University Faculty of Health Sciences Journal, 1.

Temel, F. veToran, M. (2013). Montessori egitim yontemi. F. Temel (Editor), Erkencocukluk Tezi). Marmara Universitesi Sosyal Bilimler Enstitusu, Istanbul. Theoretical framework: foundations of learning to read. InChesher, D. (Eds), Developing language and literacy effective intervention in the early years (pp. 1-16). John Wiley ve Sons, Ltd.

Toran, M. (2011). Montessori yonteminin cocuklarin kavram edinimi, sosyal uyumlari ve kucuk kas motor becerileri uzerindeki etkisinin incelenmesi. Gazi Universitesi, Ankara.

Treiman, R., Kessler, B. \& Pollo, T. C. (2006). Learning about the letter name subset of the vocabulary: Evidence from U.S. and Brazilian preschoolers. Applied Psycholinguistics, 27, 211-227.

Ulutas, Ive Tutkun, C. (2017). Montessori egitim yontemi ve uygulama ornekleri. Icinde F. Temel (Ed.), Okul oncesi egitimde alternative yaklasimlar (ss.39-68). Hedef Basin Yayin.

Whitehurst, G. J. \& Lonigan, C. J. (1998). Child development and emergent literacy. Child development, 69(3), 848-872.

Yazici, E. (2010). 61 -72 aylik cocuklar icin okuma yazma becerileri arastirma testinin gecerlik ve guvenirlik calismasi. (Yuksek lisans tezi). Gazi Universitesi, Egitim Bilim leri Enstitusu, Ankara.

Yildirim, C. (2019). Montessori yontemine dayali ogretim tasariminin birinci sinif ogrencilerinin hazirbulunusluklarina, matematik ve okuma-yazma becerilerine etkisi. (Doktora Tezi). Burdur Mehmet Akif Ersoy Universitesi, Egitim Bilimleri Enstitusu, Ankara.

\section{Biographical notes:}

Dr. Aycan BULDUR is an assistant professor doctor in the Department of Early Childhood Education at Sivas Cumhuriyet University, Turkey. Her current research interests are Montessori education, early literacy, early childhood education and environmental education.

Dr. İclal GOKKUS is an assistant professor doctor in the Department of Primary Education at Sivas Cumhuriyet University, Turkey. Her current research interests are early literacy, teaching reading and writing in primary education, teaching Turkish in primary education. 